\title{
A PROPOSAL FOR THE ABANDONMENT OF THE WRITING REQUIREMENT FOR ARBITRATION AGREEMENTS IN NATIONAL LAWS
}

\author{
VAN DAI DO* \\ Ho Chi Minh City University of Law, Vietnam \\ Email: dvdai@hcmulaw.edu.vn
}

\begin{abstract}
An arbitration agreement is an agreement in which two or more parties agree that a dispute which has arisen or may arise between them shall be resolved by one or more arbitrators. For the past decades, the written form has been a key requirement for arbitration agreements. However, there has arisen a shift in national laws towards the abandonment of this formal requirement to give the parties more freedom in the expression of their arbitration agreement. This argues for this abandonment and discusses how this can be realized in national laws.
\end{abstract}

Keywords: abandonment, arbitration agreement, freedom, national law, writing requirement

A $\mathrm{n}$ arbitration agreement is an agreement in which two or Amore parties agree that a dispute which has arisen or may arise between them shall be resolved by one or more arbitrators. The arbitration agreement reflects the will of the parties in submitting their disputes to arbitration. Thus, the parties are so bound to the extent of subjects included in the underlying arbitration agreement and may not raise those claims to national courts. There are a number of legal issues related to an arbitration agreement, including its autonomy, the capacity of the parties, the agreement's applicable law, and its form and content. However, in this study, we focus on the form of an arbitration agreement, on how the parties can express their agreement to arbitrate.

The form of an arbitration agreement is prescribed in major international legal instruments. One of them is the New York Convention of 1958 on the Recognition and Enforcement of Foreign Arbitral Awards ("New York Convention"). The New York Convention sets out the general principle that arbitration agreements must be in writing. Specifically, Article II of the New York Convention

\footnotetext{
$\star \quad$ Dean of the Faculty of Civil Law-University of Law of Ho Chi Minh-City (Vietnam); Arbitrator, Vice-President of the Scientific Council of Vietnam International Arbitration Centre (VIAC). This research is funded by Vietnam National Foundation for Science and Technology Development (NAFOSTED) under grant number 505.01-2020.02.
} 
provides that: "1. Each Contracting State shall recognize an agreement in writing under which the parties undertake to submit to arbitration all or any differences which have arisen or which may arise between them in respect of a defined legal relationship, whether contractual or not, concerning a subject matter capable of settlement by arbitration. 2. The term 'agreement in writing' shall include an arbitral clause in a contract or an arbitration agreement, signed by the parties or contained in an exchange of letters or telegrams". As Reetz put it, "it appears that art. II's writing requirement is a prerequisite both for enforcement of the parties' agreement to arbitrate and for the recognition and enforcement of any resulting award". ${ }^{1}$

The secondinstrument is UNCITRAL Model Arbitration Law ("Model Law") and the writing requirement under the 1985 version is included in Article 7(2), which reads that "The arbitration agreement shall be in writing". Here, "it requires that an arbitration agreement be in writing and defines what will constitute a writing for this purpose, using a definition modeled on the writing requirement of Article II(2) of the New York Convention". ${ }^{2}$ According to the Model Law, "the writing requirement of the 1985 Model Law is not merely a requirement that there be written evidence of the parties' consent to arbitration; the consent itself must be in writing. One reason for that requirement was the view of the original Working Group that the New York Convention required that the consent of the parties be recorded in writing. It was agreed at the outset of the drafting of the 1985 Model Law that the Law should not conflict with the New York Convention". 3

Besides the New York Convention (mandatory for member States) and the Model Law (optional for States), there are also many national laws with the provisions concerning the form of an arbitration agreement. In the past, there was a requirement that an arbitration agreement must be authenticated by a notary. For example, in the Spanish Law on Private Law Arbitration of 22 December 1953, "it

Reetz C. R. (2009), 'Recent developments concerning the "writing" requirement in international commercial arbitration: a perspective from the United States', Spain Arbitration Review, p.30. In fact, Art. IV of Convention provides as follows: 1. To obtain the recognition and enforcement mentioned in the preceding article, the party applying for recognition and enforcement shall, at the time of application, supply: (a) The duly authenticated original award or a duly certified copy thereof; (b) The original agreement referred to in Article II or a duly certified copy thereof".

2 Holtzmann H. M., Neuhaus J. and al. (2015), A Guide to the 2006 Amendments to the UNCITRAL Model Law on International Commercial Arbitration: Legislative History and Commentary, Kluwer Law International, p.30.

$3 \quad$ Ibidem., p.34. 
is required that the submission be signed before a notary public (Art. 16)" . ${ }^{4}$ Under this law, "it must always be drawn up in the form of a notarial document (escriturapúblico). The written notarial submission must contain the following: $a$. The names, professions and addresses of the parties. b. The names, professions and addresses of the arbitrators. c. The nature and circumstances of the dispute that is submitted to arbitration. d. A specific period of time within which the arbitrators must render the award. e. The place where the arbitration is to take place". ${ }^{5}$ However, on 7 December 1988, the Official State Gazette published Law 36/1988 of 5 December 1988 regulating arbitration in Spain and "the 1988 law removed this requirement for the arbitration agreement". ${ }^{6}$

Nowadays, while the notarial requirement has ceased to exist, the writing requirement remains prevalent in national laws. As Lew noted, "every legal system has formal requirements for an arbitration clause, the absence of which may result in the agreement not being enforceable". 7 This is exemplified by the laws of Asian countries. Still, the writing requirement for arbitration agreements has been well established in the law of Southeast Asian countries, including Brunei, ${ }^{8}$ Cambodia, ${ }^{9}$ Indonesia, ${ }^{10}$ Malaysia,,${ }^{11}$ Myanmar, ${ }^{12}$ Singapore,${ }^{13}$ Philippines. ${ }^{14}$ Thailand ${ }^{15}$ and Vietnam. ${ }^{16}$ This is also the case of major countries in Asia, such

4 Sanz-Pastor B. M. C., 'Arbitration in Spain', in Sanders P. (ed) (1989), Arbitration in Settlement of International Commercial Disputes Involving the Far East and Arbitration in Combined Transportation, ICCA Congress Series, ICCA \& Kluwer Law International, p.260.

Sanz-Pastor B. M. C., 'National Report for Spain', in Berg A. J. V. D. (ed) (1987), Yearbook Commercial Arbitration, ICCA \& Kluwer Law International, pp.41-42.

6 Manitlla-Serrano F. (2004), 'La nouvelle loi espagnole du 23 décembre 2003 sur l'arbitrage', Revue de l'Arbitrage, p.241.

7 Lew J. D. M., 'The Law Applicable to the Form and Substance of the Arbitration Clause', in Albert Berg A. J. V. D. (ed) (1999), Improving the Efficiency of Arbitration Agreements and Awards: 40 Years of Application of the New York Convention, ICCA Congress Series, ICCA \& Kluwer Law International, p.119.

8 Article 4(3) of the Arbitration Order 2009 (S34/2009).

$9 \quad$ Article 7 of the Commercial Arbitration Law 2006.

10 See Mills K. G., 'National Report for Indonesia (2018 through 2019)', in Paulsson J. (ed) (2019), ICCA International Handbook on Commercial Arbitration, ICCA \& Kluwer Law International, p.11.

11 Article 9(al.3) of the Arbitration Act 2005 (amended in 2018).

12 Finch J. and Aye T. (2016), 'International Arbitration Under Myanmar's Arbitration Law', Asian International Arbitration Journal, p.238.

13 Article 2A(3) of the International Arbitration Act (amended in 2012); Article 4(3) of the Arbitration Act (amended in 2012).

Article 4 of The Arbitration Law (Act n. 876).

Article 11 of Arbitration Act BE 2545 (2002).

Article 16(2) of the Arbitration Commercial Law 2010. 
as China, ${ }^{17}$ India ${ }^{18}$ and Japan. ${ }^{19}$ The writing requirement also exists in arbitration laws of non-Asian jurisdictions like England ${ }^{20}$ and Australia. ${ }^{21}$

Some countries have tried to reduce the rigidity of the writing requirement by providing a broad definition of written agreements. For example, Article 2A(3) of the International Arbitration Act of Singapore (incorporating amendments as at 1 June 2012) provides that: "An arbitration agreement shall be in writing" and the Article 2A(3) of this Act specifies that "An arbitration agreement is in writing if its content is recorded in any form, whether or not the arbitration agreement or contract has been concluded orally, by conduct or by other means". This means that the written form is still compulsory, but it is understood broadly. Korea's Arbitration (Amended) Act 2016 applies the same approach $^{22}$. Pursuant to Article 8(2) of this Act, an arbitration agreement is considered in written form as long as its content is "recorded in any form". ${ }^{23}$

In fact, "most national laws are influenced by the requirements of international instruments, especially the 1958 New York Convention and the UNCITRAL Model Law". ${ }^{24}$ However, "the New York Convention is an older instrument", 25 "often regarded as outdated" 26 and "the ramifications of an amendment, a modification or a clarification are far-reaching". ${ }^{27}$ This article, does not call to reform the New York Convention or the Model Law. Rather, it only analyzes the possibility of changes in the writing requirement for arbitration agreements in

$17 \quad$ Article 16 of Arbitration Law of the People's Republic of China.

18 Article 7(3) of the Arbitration and Conciliation Act 1996 (last amendment in 2019).

19 Article 13(2) of the Arbitration Law (Law No. 138 of 2003).

20 Article 5 (1) of the Arbitration Act 1996.

$21 \quad$ Article 3(1) of the International Arbitration Act 1974.

22 See Kim K.-Y. (K.) and Chung K., 'National Report for Republic of Korea (2018 through 2019)', in Paulsson J. (ed,), supra note 10, p.10.

23 Sippel H. (2017), 'An Overview of the Revisions to the New Korean Arbitration Act: Will Korea Now Become an East Asian Arbitration Hub?', German Arbitration Journal, pp. 90 - 95 (III-3).

24 Lew J. D. M., supra note 7, p.119.

25 Landau T. T., 'The Requirement of a Written Form For an Arbitration Agreement When "Written" Means "Oral"”, in Berg A. J. V. D. (ed) (2003), International Commercial Arbitration: Important Contemporary Questions, ICCA Congress Series, ICCA \& Kluwer Law International, p.64.

26 "It was widely considered that article II (2) of the 1958 Convention on the Recognition and Enforcement of Foreign Arbitral Awards (the New York Convention) (which required the arbitration agreement to be in written form "in a contract or an arbitration agreement, signed by the parties or contained in an exchange of letters or telegrams"), and subsequent uniform provisions modeled on that article, were often regarded as outdated" (Holtzmann H. M., Neuhaus J. and al., supra note 2, p.51).

$27 \quad$ Landau T. T., supra note 25, p.64. 
national laws. ${ }^{28}$ The main question here is whether it is necessary for the intention [of the parties] to submit the existing or future disputes to arbitration to be expressed in writing.

As mentioned above, the laws of many countries still require that arbitration agreements be in written form. However, as I will show below there has emerged a new trend that advocates a less formalistic approach to the form of arbitration agreements. The article will first argue for the abolishment of the writing requirement in domestic arbitration laws (I) and then explain how this should be implemented (II).

\section{JUSTIFICATIONS FOR THE ABANDONMENT OF THE WRITING REQUIREMENT}

The laws of a few countries do not require that arbitration agreements be in written form. In these countries, arbitration agreements can be established in a written or verbal form, or even implied by the acts of the parties.

"The 1999 Swedish Arbitration Act imposes no form requirements at all, it being established that an arbitration agreement may be concluded orally. This has long been the position in Swedish law". ${ }^{29}$ Pursuant to the Swedish Arbitration Act passed in 1929, "no particular form is prescribed for the arbitration agreement but in practice it is nearly always in writing". ${ }^{30}$ Before the reform in 1999, "according to the report established by the preparatory Committee, arbitration agreements do not require written form. Oral agreements are equally binding". ${ }^{31}$ Today, "Swedish law does not require an agreement to be in any specific form, and recognizes oral as well as written contracts". ${ }^{32}$ In this system, "no

28 According to Landau T. T. (Ibidem., p.42), "upon a proper analysis, the written form requirement is extremely difficult to justify at all, as a matter of policy as well as practice. Equally, however, there are a number of compelling reasons why the New York Convention should not be amended". Regarding Article II(1) of New York Convention, which requires Contracting States to give effect to arbitration agreement "in writing", a study also notes that "all that the provision indicates is that written agreements are to be enforced; it does not preclude the enforcement of non-written arbitration agreements. In a nutshell, Article II should not be an insurmountable bar to the enforcement by the arbitrator of a non-written arbitration agreement if that agreement is otherwise deemed valid by an applicable law" (Gomez K. F. and Lopez-Rodriguez A. M. (eds) (2019), 60 Years of the New York Convention: Key Issues and Future Challenges, Kluwer Law International, p.29).

29 Ibidem., p.57.

30 Holmback U. and Mangard N., 'National Report for Sweden', in Berg A. J. V. D. (ed) (1978), Yearbook Commercial Arbitration, ICCA \& Kluwer Law International, p.162.

31 Sherer M. (1994), 'Some brief comments on the Draft of the new Swedish Arbitration Act', ASA Bulletin, p.282.

32 Jarvin S. H. L. and Young B. (1999), 'A New Arbitration Regime in Sweden - The Swedish Arbitration Act 1999 and the Rules of the Stockholm Chamber of Commerce', Journal of International Arbitration, p.91. 
particular form is prescribed for the arbitration agreement. Oral and written agreements are equally binding". ${ }^{33}$

In Canada, "As for domestic arbitration, all Arbitration Acts, save for those adopted in Newfoundland and Labrador, Northwest Territories, Nunavut, and Yukon Territory, make an oral agreement to arbitrate possible. For example, the Alberta Arbitration Act, after defining the arbitration agreement (Sect. 1(1)(a)), clearly states that such an agreement need not be in writing (Sect. 5(1))" ${ }^{34}$ However, a lot of countries still provide the writing requirement for the arbitration agreement and we would like these countries to gradually abandon this formal requirement. In fact, the justifications for advocating the abandonment of the writing requirement come first from the weaknesses, inconveniences which come from this requirement (A). They then come from the advantages that abandonment brings to arbitration (B).

\section{A. Problems with the Writing Requirement}

\section{Unusual foundations of the writing requirement}

(a) Exclusion of access to a court: An arbitration agreement is a contract in which the parties agree to submit their existing or future disputes to arbitrators, and not to the courts. It prevents the parties from seeking the resolution by the courts of disputes covered by the arbitration agreement and the courts are prohibited from hearing such disputes. The arbitration agreement, therefore, results in the exclusion of the courts.

For some authors, this exclusion justifies the writing requirement of the arbitration agreement. T. Thomas Landau notes that "the exclusion of a court is treated as a serious step, and states therefore, have an interest, as part of the public administration of justice, to ensure that any such agreement reflects a genuine consent. One way of policing the exclusion of access to a court is to insist that the arbitration agreement be in writing. This is the most commonly cited justification for the form requirement". ${ }^{35}$ J. Lew, L. Mistellis and S. Kröll confirm the same: "as the agreement to arbitrate may lead to renunciation by the parties of their constitutional right to have their disputes decided in court, the written form aims to prevent the agreement going unnoticed". ${ }^{36}$ In his book, Gary B. Born also states that "one explanation for the writing requirement is ensuring that parties are adequately aware of their waiver

$33 \quad$ Franke U., 'National Report for Sweden (2018 through 2019)', in Paulsson J. (ed), supra note 10, p.5.

34 Lamonde M. and Alexeev L., 'National Report for Canada (2018 through 2019)', in Paulsson J. (ed), supra note 10, p. 10 .

Landau T. T., supra note 25, p.22.

Lew J. D. M., Mistellis L. A. and Kroll S. (2003), Comparative International Commercial Arbitration, Kluwer Law International, p.131. 
of otherwise-available access to national courts and judicial remedies when agreeing to arbitrate and of the gravity of their commitment to arbitrate". ${ }^{37}$

However, F. Villaggi points out that "arbitration has always been the natural forum to resolve international commercial disputes. Proarbitration jurisdictions, like France, have abandoned the writing requirement". ${ }^{38} \mathrm{~J} .-\mathrm{B}$. Racine affirms the same thing when he writes that "moreover, since arbitration is the common law of international affairs, the stipulation of an arbitration agreement is natural, even usual. There are no formal requirements to be met'. ${ }^{39}$ The author agrees with these experts' approach that the exclusion of the courts from hearing disputes is not a solid justification and there is no justification to submit arbitration agreements to stricter form requirements than other contractual provisions. ${ }^{40}$

(b) Proof of arbitration agreement: The evidentiary function is often invoked to justify the writing requirement of the arbitration agreement.

T. Thomas Landau notes that "aside from considerations concerning initial consent, the written form requirement has also been justified on the basis of overall certainty within the arbitral process itself. In other words, once parties have consented to arbitration, there is an interest in ensuring that the type of arbitration, and the terms of the process, are clear and susceptible of proof'. ${ }^{41}$ Gary B. Born also points out that "the written form requirement is also sought to be explained on the grounds that it provides a readily-verifiable evidentiary record of the parties' agreement to arbitrate". ${ }^{42}$

In fact, there is no doubt that "writing provides a record of the agreement which helps to prove the existence and the content of an arbitration agreement in subsequent proceedings". ${ }^{43}$ However, the proof of arbitration agreement can be brought by other means such as actions, witnesses and admission. So, the evidentiary function is also not a solid justification of the writing requirement of the arbitration agreement.

37 Born G. B. (2014), International Commercial Arbitration, Kluwer Law International, p.660.

38 Villaggi F. (2018), 'Recent Developments in the Arbitration Legislation in Argentina', Journal of International Arbitration, pp. 225 - 252 (3.3).

39 Racine J.-B. (2016), Droit de l'arbitrage, Puf, p.195.

40 "Arbitration is no longer considered a dangerous waiver of substantial rights. In fact the selection of arbitration is not an exclusion of the national forum but rather the natural forum for international disputes". Lew J. D. M., Mistellis L. A. and Kroll S., supra note 36, p.132.

41 Landau T. T., supra note 25, p.23.

42 Born G. B., supra note 37, p.661.

43 Lew J. D. M., Mistellis L. A. and Kroll S., supra note 36, p.131. 


\section{Inconveniences of the writing requirement}

(a) Non-conformity with practices: Requirement of written form is considered as not taking into account the diversity of the practice. "Too strict a formalism would be incompatible with the way in which many international contracts are concluded in practice, and would moreover be unjustified, given the natural nature of arbitration as a means of resolving international trade disputes". ${ }^{44}$

In fact, "form requirements sometimes do not always reflect business practice. While in certain areas of trade parties often rely on oral agreements, strict form requirements can defeat an agreement to arbitrate, the existence of which is beyond doubt. It has been criticised correctly that the parties can orally agree on a multi-million dollar contract which will be considered to be valid but for the arbitration clause. The arbitration agreement would be invalid irrespective of whether it can be established that the parties actually agreed on arbitration. A party can enforce the substantive provisions of a contract while being able to walk away from the agreement to arbitrate concluded at the same time". ${ }^{45}$ A UNCITRAL's report affirms this weakness of the writing requirement: "it has been repeatedly pointed out by practitioners that there are a number of situations where the parties have agreed to arbitrate (and there is evidence in writing about the agreement), but where, nevertheless, the validity of the agreement is called into question because of the overly restrictive form requirement. The conclusion frequently drawn from those situations is that the definition of writing, as contained in [various] international legislative texts, is not in conformity with international contract practices and is detrimental to the legal certainty and predictability of commitments entered into in international trade". ${ }^{46}$ A comparative study further highlights that "there are in fact many examples of arbitration agreements and awards that have been defeated by reason of a failure to satisfy a written form requirement. The nature of the form requirement is such that it presents a potential threat to the arbitral process at every stage". ${ }^{47}$ From a practical point of view, "it is difficult to avoid the conclusion that historic written form requirements (and related "signature" and "exchange" requirements) are ill-suited to,

$44 \quad$ Mayer P. (1994), 'De l'autonomie de la clause compromissoire', Revue critique du droit international privé, p. 663.

45 Lew J. D. M., Mistellis L. A. and Kroll S., supra note 36, p.131.

46 UNCITRAL, Working Group II (Arbitration), Uniform Rules on Certain Issues Concerning Settlement of Commercial Disputes: Conciliation, Interim Measures of Protection, Written Form for Arbitration Agreement, Report of the Secretary General (U.N. Doc. A/CN.9/ WG.II/WP.108/Add.1, 7, 2000).

47 Landau T. T., supra note 25, p.34. 
and unnecessary in, contemporary international business transactions between commercial parties". ${ }^{48}$ The above authors rather speak of the weakness of the written form for international arbitration but the same reasoning also applies to domestic arbitration. We will see that France abandons the writing requirement for international arbitration and maintains it for domestic arbitration but, according to the French doctrine, "this difference is not appropriate since nothing justifies such a difference in the solutions". ${ }^{49}$

To further illustrate that the requirement of the written form departs from practice and current trend, two following instruments which have a great influence on the practice of international contracts and on national contract laws are mentioned herein. The first instrument is Article 2: 101 (2) of the Principles on European contract law, "A contract need not be concluded or evidenced in writing nor is it subject to any other requirement as to form. The contract may be proved by any means, including witnesses". The second one is the UNIDROIT Principles of International Commercial Contracts, which provides the same approach that "Nothing in these Principles requires a contract, statement or any other act to be made in or evidenced by a particular form. It may be proved by any means, including witnesses" (Article 1.2). According to those Principles, the conclusion of a contract is not subject to any requirement as to form, which testifies that the writing requirement in arbitration does not align with current practices.

(b) Disregard of the real will of the parties: The requirement of written form can lead to missing the real will of parties that exists in reality. For example, Article 9(2) of the Saudi Arbitration Law states that "the arbitration agreement shall be made in writing, failing which it shall be null and void". In this system, "the arbitration agreement is a formal agreement concluded exclusively in writing. Failing which, the agreement cannot be established, even by confession or oath" ${ }^{50}$ and "an arbitration agreement or contract cannot be concluded orally". ${ }^{51}$ It means that an arbitration agreement is not recognized valid when it is not written although it really exists between the parties.

To further illustrate this problem, the following case is reviewed. Six people (defendants, debtors) have signed a written document acknowledging the debt owed to another person (claimant, creditor).

$48 \quad$ Born G. B., supra note 37, p.662.

49 Racine J.-B., Droit de l'arbitrage, supra note 39, p.195.

50 Hẹainlan S. A. (2012), 'The New Saudi Arbitration Act: A Comprehensive and Article-byArticle Review', International Journal of Arab Arbitration, p.24.

51 Zegers J.-B., 'National Report for Saudi Arabia (2019)', in Paulsson J. (ed), supra note 10, p.14. 
In this written document, there is an arbitration clause. The creditor initiated legal actions against the debtors based on this written document and the arbitrators declared themselves competent, decided the case. The debtors sought for setting aside the arbitral award after its issuance. The judges consequently set aside the award on the ground that "it is not in conformity with the form of arbitration agreement according to Article 16 of the Law on commercial arbitration of Vietnam", ${ }^{2}$ which provides that "An arbitration agreement must be in writing".

In the above case, the will of the debtors in favor of arbitration is clearly found in the written instrument of acknowledgment of debt but, as the court said, "it is only a unilateral will of the debtors". ${ }^{33}$ The fact that the creditor initiated arbitration on the basis of a written document including an arbitration clause also clearly shows the will of the creditor for arbitration. However, the common will of the two parties is not in writing and this leads judges to deny the jurisdiction of arbitrators on the basis of the written form required by law. This decision of the court shows that the requirement of the written form for the arbitration agreement can lead to ignoring the real will of the parties and it is therefore not a reasonable solution.

(c) Creation of parasitic disputes: The writing requirement for the arbitration agreement creates parasitic disputes, especially when a party seeks to escape arbitration while it has consented to arbitration in an unwritten form. A comparative study in 2003 already underlined that "Form requirements do not necessarily promote legal certainty; they are often the source of additional disputes". ${ }^{54}$

In fact, the writing requirement raises disputes concerning the question of whether this requirement is made for validity (according to some countries, this is a requirement for the validity of the agreement $)^{55}$ or only for proof (some laws "expressly state, or can be interpreted as

\footnotetext{
Decision $n^{\circ} 02 / 2018 /$ QĐ-KDTM (25/1/2018) of the Ha Noi People's Court (Vietnam). Decision n ${ }^{\circ} 02 / 2018 / \mathrm{Q} Đ-K D T M(25 / 1 / 2018)$ of the Ha Noi People's Court (Vietnam). Lew J. D. M., Mistellis L. A. and Kroll S.,supra note 36, p.132.

For example, the article 16(a) of Law on Commercial Arbitration of Vietnam (No. 54/2010/ $\mathrm{QH} 12)$ regulates that "An arbitration agreement must be in writing" and the article 18(4) of this law provides that the arbitration agreement is void when "the form of the arbitration agreement does not comply with article 16 of this Law". The same solution is found in Syrian law where the Article 8 of the Arbitration Act (Law No. 4 of 2008) stipulates that "the arbitration agreement must be in writing; otherwise it shall be null and void" (see also El-Ahdab A. H. and El-Ahdab J. (2011), Arbitration with the Arab Countries, Kluwer Law International, p.703). In Algeria, the new domestic arbitration law stipulated that "the arbitration clause, under penalty of nullity, is proven in writing in the original agreement or in the document it is based thereon" (see also El-Ahdab A. H. (2009), 'The new Algerian arbitration law', International Journal of Arab Arbitration, pp. 9 - 87).
} 
stating, that a written document is merely required ad probationem"), ${ }^{56}$ especially in cases where the text is not clear. For example, Article 16 of the Arbitration Law of the People's Republic of China imposes the formal requirement ${ }^{57}$ and the article 17 of this Law provides the circumstances of nullity of an arbitration agreement but this Article 17 does not mention the written defect ${ }^{58}$ (according to a study, it is a condition of validity). ${ }^{59}$ When it is a condition of validity, the question arises as to whether it is a relative nullity ${ }^{60}$ or an absolute nullity. ${ }^{61}$ When it is a condition of validity, the question still arises also as to whether we can apply the rules regarding the nullity of contracts, in particular, the rules favorable to the safeguard of the contract. ${ }^{62}$

In conclusion, it is likely that "formal conditions are likely to give rise to parasitic disputes". ${ }^{63}$ This means that the writing requirement for arbitration agreement contains in itself a significant weakness.

\section{B. Advantages of Abandonment of Writing Requirement}

1. Elimination of practical problems caused by the writing requirement

(a) Conformity with the practice: "It is often observed that contracts of very high value are concluded orally every day" ${ }^{\text {". }}$. Practice shows

$56 \quad$ Gaillard E. and Savage J. (eds) (1999), Fouchard Gaillard Goldman on International Commercial Arbitration, Kluwer Law International, p.369.

57 "An arbitration agreement shall include arbitration clauses stipulated in the contract and agreements of submission to arbitration that are concluded in other written forms before or after disputes arise" (for this requirement of written form, see also Lu SONG, "National Report for China (2014 through 2018)', in Bosman L., (ed) (2019), ICCA International Handbook on Commercial Arbitration, ICCA \& Kluwer Law International, p.18).

58 "An arbitration agreement shall be null and void under one of the following circumstances: (1) the agreed matters for arbitration exceed the range of arbitrable matters as specified by law; (2) one party that concluded the arbitration agreement has no capacity for civil conducts or has limited capacity for civil conducts; or (3) one party coerced the other party into concluding the arbitration agreement".

59 This study asserts that "both Chinese arbitration law and the Hong Kong Ordinance require a written document for the agreement to be valid. Verbal arbitration agreement therefore has no effect in Chinese Law" (Fan K., Stackpool-Moore R. and El-Ahdab J. (2014), 'Un point (de vue) actuel sur l'arbitrage en Chine et à Hong Kong: Toujours un pays, deux systèmes?', Revue de l'Arbitrage, p.838)

60 In Romania "the condition of the written form is an ad validitatem requirement, nullity being the sanction. In lack of an express specification, however we consider that nullity is relative and not absolute as the protected interest is that of the parties and not a general one. As said, the parties may overcome this issue of nullity if the respondent does not claim the nullity of the arbitration agreement for the lack of fulfilling the written form requirement" (Leaua C. and Baias F.-A. (eds) (2016), Arbitration in Romania: A Practitioner's Guide, Kluwer Law International, p.101).

${ }_{61}$ For Syria, "it is deemed to be a formal condition without which the whole agreement would be null and void, this nullity being absolute, and affecting public policy (Court of Cassation, decision no. 90 of February 15, 1962)" (El-Hakim J., 'National Report-Syria', in Berg A. J. V. D. (ed) (1982), Yearbook Commercial Arbitration, ICCA \& Kluwer Law International, p.36).

62 In Vietnam, the current Civil Code makes it possible to save the contract which does not meet the formal condition when this contract has been executed for $2 / 3$ (article 129) or when the period of 2 years to request nullity has expired (article 132). Today, we do not know if these rules also apply to the arbitration agreement.

63 Racine J.-B., 'Fasc. 750', in Juris-classeur Droit international (Lexisnexis 2017), nº 23.

64 Landau T. T., supra note 25, p. 47. 
that the arbitration agreement formed between the parties can be written or unwritten and it is frequent that "the parties concluded an agreement orally or by conduct that referred to standard conditions in the industry, a standard set of procedural rules or even simply to the national law (including the arbitration law) of a particular country". ${ }^{65}$ In April 2002, the Working Group of UNCITRAL considered two interesting examples about that: "(a) the case where a maritime salvage contract was concluded orally through radio with a reference to a preexisting standard contract form containing an arbitration clause, such as the Lloyd's Open Form; (b) contracts concluded by performance or by conduct (for example a sale of goods under Article 18 of the United Nations Convention on Contracts for the International Sale of Goods), with reference to a standard form containing an arbitration clause, such as documents established by the Grain and Food Trade Association (GAFTA) ....". ${ }^{66}$ Arbitration legislation cannot ignore this fact and must take it into account so that it has to abandon the writing requirement for the arbitration agreement.

In fact, Belgium, taking into account the practice described above, has abandoned the writing requirement of arbitration agreements. In this country, "the legislator thus wished to register in the modern conception of arbitration which accepts the conclusion of agreements not written, taking into account in particular that in certain sectors of activity economical, writing is not required; the preparatory works expressly cite maritime transport and the diamond sector". ${ }^{67}$ Here, "by no longer requiring the arbitration agreement to be in writing, the Belgian legislator opted for a modern definition of the arbitration agreement. Article 1681 B.J.C. demonstrates that the Belgian legislators are cognizant of recent trends in today's business environment, of the reality of informal transactions, and of new trends in (often electronic) communication". ${ }^{68}$ The same approach is provided in the comments of various French authors for the French legal reform. Consequently, the writing requirement of an arbitration agreement is removed from the French legal system and, according to C.Nourissat, "Chapter I, devoted to the international arbitration agreement, is in substance (even if the letter may change) in the line of flexibility which necessarily prevails in this area. Thus, the agreement is not subject to any formal condition,

\footnotetext{
65 Holtzmann H. M., Neuhaus J. and al., supra note 2, p.36. Ibidem., p.36.

Caprasse O. (2013), 'Le nouveau droit belge de l'arbitrage', Revue de l'Arbitrage, p.959. Bassiri N. and Draye M. (eds) (2016), Arbitration in Belgium, Kluwer Law International, p.83.
} 
which allows to better accommodate the most varied practices that exist in this area". ${ }^{69}$

In summary it can be concluded that "in order to accommodate not only current developments in arbitration practice, but also likely future developments, the view was expressed that it might be appropriate to consider removing the writing requirement and aligning the practice with respect to arbitration agreements with that of contracts more generally" ${ }^{70}$

(b) Prevention of parasitic litigation: Practical interest of eliminating the formal requirement is "either to avoid that a written clause is the subject of challenges for formal reasons, or to allow easier entry of clauses by reference". ${ }^{71}$

According to J.-B. Racine, "the arbitration agreement takes effect regardless of the form adopted. If consent to arbitration is required, it does not matter how it is expressed ("bare" consent is sufficient). It is, of course, an objective of favor towards arbitration which is aimed. The goal is to avoid that formal obstacles (possibly instrumented by a party in bad faith who wishes to escape arbitration) do not prevent the effectiveness of the arbitration agreement (which also makes it possible to prevent the creation of parasitic litigation)". ${ }^{72}$ Similarly, according to A. Sabater, "the laws of the seat and the applicable arbitration rules contain provisions on the validity of the clause. Sometimes these provisions will be consistent (for instance, when they require written form), which makes at least one of them redundant; other times, they will be inconsistent (for instance, when one requires written form and the other not, or when both require written form but in different terms), thus giving rise to potential conflicts. Dropping formal requirements from the laws of the seat and the applicable rules reduces these problems". ${ }^{73}$

Basically, "if no written form is needed, then there is no reason to enquire what "written form" means and whether it has been complied with in the case at issue". ${ }^{74}$ Therefore, it prevents the creation of parasitic litigation.

\footnotetext{
69 Nourissat C. (2011), 'Le nouveau droit français de l'arbitrage (décret n 2011-48 du 13 janvier 2011 portant réforme de l'arbitrage)', $n^{\circ} 3$ Procédures, étude 3 ( $\left.{ }^{\circ} 12\right)$.

70 Sorieul R. (2005), 'UNCITRAL's Current Work in the Field of International Commercial Arbitration', Journal of International Arbitration, p.544.

71 Jarrosson C. and Pellerin J. (2011), 'Le droit français de l'arbitrage après le décret du 13 janvier 2011', Revue de l'Arbitrage, p.64.

Racine J.-B., Droit de l'arbitrage, supra note 39, p.195.

Sabater A. (2013), 'Survivals and New Arrivals', in Berg A. J. V. D. (ed) (2013), International Arbitration: The Coming of a New Age?, ICCA \& Kluwer Law International, p.100.

See Ibidem., p.99.
} 


\section{Strengthening of arbitration}

(a) Respect for the parties' will: We have seen that the requirement of the written form for the arbitration agreement can lead to ignoring the real will of the parties when this common will is not written. Such weakness can be eliminated when we abandon the requirement of the written form, leaving the parties free to express their will.

According to a study, "when French law still required written form for the clause, local courts could not agree on whether an arbitration agreement contained in a contract signed by just one party but performed by both was valid". ${ }^{75}$ In France today as we will see, there is no writing requirement for international arbitration, "an arbitration agreement is effective in accordance with the common intention of the parties without any other condition regarding validity which may be imposed in the otherwise applicable national law governing the arbitration agreement" agreement is only determined before the French courts based on the "common intent of the parties". ${ }^{77}$ In this actual system, the eviction of any formal condition "prohibits the judge from declaring the invalidity in the form of the arbitration agreement"78 and "only obliges to verify the consent of the party who opposes its commitment to arbitration, without imposing any specific terms on its exteriorization". ${ }^{79}$

This shows that the requirement of the written form can lead to ignoring the real will which nevertheless exists and such a desperate reality can be avoided with the abandonment of writing requirements. In other words, removing the requirement that the arbitration agreement must be "in writing" respects better the real will of the parties in matters of arbitration, a strong need to develop arbitration.

(b) Reinforcement of party autonomy: "One of the traditionally vaunted interests of arbitration is to allow the parties to make the bespoke prevail over the ready to wear. They must, in fact, be able to enjoy benefits of exercising the autonomy of their will, in the very choice of remedy to private justice, the composition of the court, the establishment of the procedure, or still in the choice of applicable". ${ }^{80}$

\footnotetext{
$75 \quad$ See Ibid., p.99.

76 Castellane B. (2011), 'The New French Law on International Arbitration', Journal of International Arbitration, p.373.

77 Bensaude D., 'French Code of Civil Procedure (Book IV), Article 1507 [The arbitration agreement]', in Mistelis L. A. (2015), Concise International Arbitration, Kluwer Law International, p.1136. Ancel M.-E., Deumier P. and Laazouzi M. (2017), Droit des contrats internationaux, Sirey, p.319. Ibidem. Caprasse O., supra note 67, p.958.
} 
We will see that there is a reform in 2013 in Belgium. Here, "until now, a written document was required to prove the existence of the arbitration agreement. This is no longer the case; the existence of an arbitration agreement can be proven by any legal means". ${ }^{81}$ Preliminary activities for the reform in 2013 indicate that "the convention can also be verbal as long as it can be proven. This evidence can be brought for example by witnesses". ${ }^{82}$ With reform in 2013 , there is then a "freedom also as to the form of the arbitration agreement" 83 and we can say that "eager to promote arbitration, the new Belgian law has, in this sense, strengthened the areas of freedom given to the parties" ${ }^{84}$ We will also see that Article 1507 of the French CCP after the reform in 2011 provides "the arbitration agreement is not subject to any formal requirement" and, according to the French doctrine, "we reach with such rule the heights of liberalism. The text provides for the most liberal rule that can be imagined". 85

With the abandonment of the written form, the Belgian Law and the French Law have left to the autonomy of will the freedom to choose the form of an arbitration agreement. Here, these laws reinforce the party autonomy and this is necessary to develop the arbitration.

(c) Enhancing the credibility of arbitration: The writing requirement of the arbitration agreement is partly justified by a certain vein of mistrust towards arbitration. In fact, "arbitration agreements have major effects, paramount among which is the removal of a dispute from national courts - to which many constitutions still grant citizens a fundamental right of access - and the transfer of the case for adjudication to private, largely unsupervised and potentially unaccountable individuals namely the arbitrators. Not that long ago, the almost unanimous view of legislators - and of the occasionally self-protective judiciary - was that the existence of any such powerful and relatively "abnormal" agreement had to be clearly established - hence the written form requirement". ${ }^{86}$ Therefore, with the abandonment of this form requirement, "a certain vein of mistrust towards arbitration agreements in particular and arbitration in general is disappearing" $" 87$ and arbitration would gain the credibility to develop.

In reality, countries that abandon the written form of arbitration agreement do not hide their intention to strengthen arbitration in their

Ibidem., p.959.

Ibidem., p.959.

Ibidem., p.959.

Ibidem., p.958.

Racine J.-B., Droit de l'arbitrage, supra note 39, p.194.

Sabater A., supra note 73, p. 100.

Ibidem. 
country. We will see that the Scottish law of 2010 does not impose the written form for arbitration agreement and, according to a Scottish author, "the 2010 Act will certainly be a major improvement on the common law, and will help to boost Scotland's international credibility as a place to do arbitration business. It has been suggested that Scotland has all the necessary attributes to become a popular seat of international arbitration". ${ }^{88}$ Such an idea is found in France where the reform in 2011 affirms the abandonment of the written form for the arbitration agreement: According to French authors, "French arbitration law is therefore extremely liberalism: no form is required for the international arbitration agreement. The aim is to promote the use of arbitration by preventing formal obstacles from hampering the effectiveness of the agreement" 89 and "recourse to arbitration should be encouraged. Consequently, it is not advisable to require a writing, because it would then be a form of distrust towards the institution. The obligation to write a writing would in reality be an obstacle to arbitration. Consensualism, as in other fields, is synonymous with liberalism and favors the conclusion of agreements, by not imposing any form"..$^{90}$

In fact, "there is no reason to subject the arbitration agreement to criteria stricter than those applied to any other contract, which can be concluded orally. The requirement seems to reflect an old conception that arbitration is a risky jurisdiction and the arbitration agreement a waiver of the right to have the dispute resolved by a judge. Such an approach is completely unjustified". ${ }^{91}$ We can then say that the abandonment of writing requirement shows the disappearance of mistrust towards arbitration and, with this abandonment, arbitration no longer constitutes, in the eyes of legislators and courts, the strange creature or foe of yore. Consequently, arbitration undoubtedly gains the credibility to develop when the legislator and the judge are in favor of the abandonment of the written form for an arbitration agreement.

\section{POSSIBLE APPROACHES TO THE ABANDONMENT OF THE WRITING REQUIREMENT}

In the previous part, we have advanced the arguments in order to abandon the written form for arbitration agreement in national laws. The historical study also shows that the requirement of writing is not an inherent solution to the arbitration agreement because, in the 5th-

\footnotetext{
88 Wilson D. (2010), 'The Resurgence of Scotland as a Force in International Arbitration: The Arbitration (Scotland) Act 2010', Journal of International Arbitration, p.687.

Racine J.-B., 'Fasc. 750', supra note 63, n 1.

Ibidem., $\mathrm{n}^{\circ} 23$.

Villaggi F., supra note 38, 3.3.
} 
4th centuries before Christ, arbitration in classical Greek law did not impose this form. In fact, "in Athens of the 5th and 4th centuries, arbitration experienced a quite remarkable boom" 92 and "as the law does not subject it to any modality, the arbitration agreement may be concluded orally or in writing, in the presence of witnesses or without any advertising". ${ }^{93}$ Now we are considering the ways to eliminate this formal requirement (A) and the scope of reducing the significance of the formal requirement (B).

\section{A. Ways to Abandon the Writing Requirement}

1. Omitting the formal condition

(a) Norwegian law 2004: The first way to eliminate the formal requirement is that legislator does not say about this formal requirement when he defines the arbitration agreement and the development of Norwegian law deserves first to be presented.

Arbitration in Norway was first regulated in Chap. 32 (Sect. 452473) of the Norwegian Civil Procedure Act of 1915 and "Sect. 452, para. 2 , requires that the arbitration agreement be in writing. It means that a signed document must exist or the parties must have clearly expressed in writing in another manner that a certain legal dispute is to be decided by arbitration". ${ }^{94}$ The New Norwegian Arbitration Act of 14 May 2004 entered into force on 1 January 2005 and this "Norwegian Arbitration Act does not require an arbitration agreement to be in writing": ${ }^{95}$ Sect. 10 of the 2004 law gives a definition to the arbitration agreement by no longer requiring the written form. ${ }^{96}$ In this system, "due to the fact that there is no longer a requirement that the arbitration agreement be in writing, new legal questions arise. If the parties have had a long-lasting business relationship during which they have used a standard contract containing an arbitration clause, according to Norwegian contract law the parties may be considered to be bound by this arbitration clause although they have not made written reference to it in a particular situation". ${ }^{97}$

\footnotetext{
92 Velissaropoulos-Karakostas J. (2000), 'L'arbitrage dans la Grèce antique-Epoques archaïque et classique', Revue de l'Arbitrage, p.18.

Ibidem., p.20.

94 Eckhoff E. F., 'National Report for Norway', in Berg A. J. V. D. (ed) (1980), Yearbook Commercial Arbitration 1980, ICCA \& Kluwer Law International, p.98.

95 Ryssdal A. and Myrbakk K. S., 'National Report for Norway (2009 through 2016)', in Paulsson J. (ed), supra note 10, p.2.

96 "The parties may agree to submit to arbitration disputes which have arisen, as well as all or certain disputes which may arise in respect of a defined legal relationship. Unless otherwise agreed between the parties in the arbitration agreement, the arbitration agreement shall be included in case of assignment of the legal relationship to which the arbitration agreement applies".

$97 \quad$ Ryssdal A. and Myrbakk K. S., supra note 95, p.6.
} 
So we see that, with reform in 2004 in Norway, "the earlier requirement that the arbitration agreement be in writing has been eliminated under the new Act". ${ }^{98}$

(b) Model Law 2006: This way also is used in the Model Law when modified in 2006. In fact, the 2006 amendments to the Model Law offered enacting States an option of dispensing with the writing requirement entirely. ${ }^{99}$

This is Article 7 Option II with the following content: "Arbitration agreement is an agreement by the parties to submit to arbitration all or certain disputes which have arisen or which may arise between them in respect of a defined legal relationship, whether contractual or not". Here, "Option II defines an arbitration agreement and omits any requirements regarding the form of the agreement". ${ }^{100}$ This "Option II eliminates the writing requirement altogether"101 and "Arbitration agreements in any form, including oral agreements, may therefore be recognized as valid under Option II" ${ }^{102}$ With Article 7 Option II, there is then a "liberalization of the writing requirements of the Model Law". ${ }^{103}$

In fact, the text of Option II was proposed by the Government of Mexico in February 2005 for consideration by the Working Group as a revision of the then draft amendment of Article 7(2). Mexico's proposal reasoned that the written form requirement is no longer justified because arbitration is "more widely accepted" now than when the New York Convention and 1985 Law were prepared and, as a result, the formality of a writing requirement "may frustrate the legitimate expectations of the other parties" to an arbitration agreement. The written form of an arbitration agreement, the Mexico proposal noted, is inconsistent with "the freedom of form" that is said to apply to commercial contracts generally. It was also said that a number of countries have reformed their arbitration laws to eliminate a form requirement or have defined the permissible form so broadly that the requirement has in practice disappeared. ${ }^{104}$

(c) Scottish law 2010: We have seen the proposition of Mexico "might depart too radically from traditional legislation, including the New York Convention" 105 and it is followed in Option II of the Model

\footnotetext{
98 Berg A. J. V. D. (ed) (2005), Yearbook Commercial Arbitration, ICCA \& Kluwer Law International, p.337.

Holtzmann H. M., Neuhaus J. and al., supra note 2, p.30.

Ibidem., p.44.

Reetz C. F. (supra note 1), p.33.

Holtzmann H. M., Neuhaus J. and al., supra note 2, p.44.

Ryssdal A. and Myrbakk K. S. (supra note 95), p.5.

Holtzmann H. M., Neuhaus J. and al., supra note 2, p.45.

Ibidem., p. 45 .
} 
Law. In reality, this option has been recognized under other laws and we can cite here the case of Scotland.

The pre-2010 Scots domestic arbitration law was antiquated (with the Articles of Regulation 1695 and the Arbitration Act 1894) and Law Reform Scotland Act 1990 (section 66) adopted the Model Law on International Commercial Arbitration for international arbitrations held in Scotland. However, this inadequate system was replaced on 7 June 2010 by a unitary law applicable to all arbitrations, ${ }^{106}$ which "resolved all the many weaknesses, omissions, grey areas, imprecisions, anomalies etc. of the pre-2010 domestic law by modern provisions". ${ }^{107}$ In reality, before the reform in 2010 , we did not see a general rule requiring the written form for domestic arbitration ${ }^{108}$ and, for international arbitration, as Scotland adopted the Model Law in its initial version so that the written form was imposed on international arbitration. Today, according to the Article 4 of the 2010 Act, "An arbitration agreement is an agreement to submit a present or future dispute to arbitration (including any agreement which provides for arbitration in accordance with arbitration provisions contained in a separate document)". This definition is similar to the definition in the Model Law in its 2006 version (Article 7 Option II) and "there is no express provision in the 2010 Act stating that the arbitration agreement must be in writing. Consequently, oral agreement to go to arbitration will be subject to the 2010 Act's provisions". ${ }^{109}$

In other words, under the new Act (which defines an arbitration agreement and omits any requirements regarding the form of the agreement), the parties are now free to choose the form of their arbitration agreement and "the 2010 Act covers oral arbitration agreements". ${ }^{110}$

(d) Belgian law 2013: The Option II of Model Law also has been recognized under Belgian law Arbitration (governed by the Judicial Code, B.J.C). In the past, "any arbitration agreement must be constituted by an instrument in writing signed by the parties, or by other documents binding on the parties and showing their intention to have recourse to arbitration (Art. 1677)". ${ }^{111}$ In this period, pursuant to Article 1677 Old B.J.C., an arbitration agreement had to be contained either in a

106 Dundas H. R. (2010), 'The Arbitration (Scotland) Act 2010-A New Era Begins', Asian Dispute Review, p.108.

107 Dundas H. R. (2016), 'The Arbitration (Scotland) Act 2010: A Great Collaborative Success and an Innovative Model for Other Jurisdictions to Follow', Indian Journal of Arbitration Law, p.89.

108 Weir M. E. L. (1987), 'Arbitration in Scotland', Journal of International Arbitration, p.36.

109 Wilson D., supra note 88, p.685.

110 Dundas H. R., supra note 107, p.94.

111 Matray L. (1980), 'National Report for Belgium', in Berg A. J. V. D. (ed), Yearbook Commercial Arbitration, ICCA \& Kluwer Law International, p.4. 
written and signed document or in other documents that are binding on the parties and that reveal their intent to resort to arbitration ${ }^{112}$ but the formal requirements of Article 1677 Old B.J.C. are in any case no longer repeated under the new Belgian law on arbitration. ${ }^{113}$

In reality, the new Article 1681 of B.J.C defines the arbitration agreement as "an agreement by the parties to submit to arbitration all or certain disputes which have arisen or which may arise between them in respect of a defined legal relationship, whether contractual or not". This definition is a true copy of Article 7 (Option 2) of the UNCITRAL Model Law ${ }^{114}$ with a particularity that "Article 1681 B.J.C. gives a definition of an arbitration agreement and sets out the formal validity requirements that an arbitration agreement must meet"115, it "does not impose any formal requirements". 116

So the new law 2013 does not require that the arbitration agreement consists of an instrument in writing signed by the parties, as was the case under the previous legislation where a written instrument was required ${ }^{117}$. According to the Belgian doctrine, "by not (no longer) requiring that the arbitration agreement be in writing, the Belgian legislator opted for a modern definition of the arbitration agreement". ${ }^{118}$

2. Reaffirming the absence of a formal condition

(a) French law 2011: The second way to eliminate the formal requirement of an arbitration agreement is that legislators do not request the written form and also specifies that the arbitration agreement is not a subject to any formal condition. This is a French case.

French law has adopted this view in 2011 because Article 1507 of the French CCP now provides: "The arbitration agreement is not subject to any formal requirement". Here, the legislator does not require the written form for the arbitration agreement and it goes further by clarifying the absence of the writing requirement. With the solution like in France, "it is enough that an agreement exists, whether express or tacit"119 and "oral or tacit international commercial arbitration agreements should, as a matter of principle, be valid in the same way that most other oral or tacit international commercial contracts may be valid". ${ }^{120}$ Legally, the first way (like in Norway, in Model Law, Scotland

Bassiri N. and Draye M. (eds), supra note 68, p.79.

Ibidem., p.80.

Piers M. and Meulemeester D. D. (2013), 'The New Arbitration Law - Belgium Adopted the UNCITRAL Model Law', Asian International Arbitration Journal, p.153.

Bassiri N. and Draye M. (eds), supra note 68, p.73.

Ibidem., p.83.

Dal M., 'National Report for Belgium (2019)', in Paulsson J. (ed), supra note 10, p.99.

Piers M. and Meulemeester D. D., supra note 114, p.153.

Racine J.-B., 'Fasc. 750', supra note 63, n 22.

Born G. B., supra note 37, p.662. 
and Belgium) is sufficient to eliminate the writing requirement because not talking about the form of arbitration agreement means there is no requirement of the form for this agreement. However, faced with an actual over-dominance of the written form for the arbitration agreement, the solution as in French law is desirable to make things clearer and avoid unnecessary controversy. ${ }^{121}$

Thus, we can say that "the wording is also negative: the agreement is not subject to any formal conditions. It would certainly have been possible to dispense with such a rule (which, in the strict sense, poses no conditions). But it seemed useful to affirm this in the context of greater intelligibility of the regime". ${ }^{122}$

(b) Before and after reform: The French way above is not isolated. Such a way is already found in the Unidroit Principles and the Principles on European contract law that we mentioned above. To better understand the French solution, we compare the French situation before and after the reform of 2011.

Before the reform in 2001, the formal requirement clearly results from article 1443 of CCP (in domestic arbitration), which requires a written document under penalty of nullity. In fact, "Former Arts. 1443 and 1444 of the CCP set forth two basic requirements of domestic French arbitration law for the form of the arbitration agreement: it must be in writing in order to be valid"123. "But the texts on international arbitration are silent"124 and "Jurisprudence is no clearer" 125 during this period. So, there was a strong controversy: a part of French doctrine "sees an extension to international arbitration of the rule of article 1443 New CPC" 126 but another part of French doctrine has believed that French law has adopted the principle of consensualism and a "writing being only desirable ad probationem". ${ }^{127}$ With the reform in 2001, such controversy disappears, they are very happy to develop arbitration.

$121 \quad$ Clay T. (2012), 'Liberté, Égalité, Efficacité: La devise du nouveau droit français de l'arbitrage Commentaire article par article (Deuxième partie)', Clunet $n^{\circ} 3$, doctr. 8, Article 1507) notes that "We could therefore legitimately find this article useless since the rule of law is intended in principle to prescribe and not to state that there is no rule. However, this assertion is not unnecessary and takes up a classic solution which aims to allow the validity or recognition of all arbitration agreements, including the most informal, such as for example those which would be concluded only orally".

122 Racine J.-B., 'Fasc. 750', supra note 63, $\mathrm{n}^{\circ} 1$.

${ }^{123}$ Derains Y. and Kiffer L., 'National Report for France (2013 through 2018)', in Paulsson J. (ed), supra note 10, p.13.

124 Mayer P., supra note 44, p. 663,

125 Ibidem.

126 Ibidem.

127 Ibidem. 
We can also understand the current French solution through the Scottish situation. In fact, we understand that the Arbitration (Scottish) Act 2010 has no provision for the formal requirement and this silence about the formal requirement can cause controversy regarding the form of the arbitration agreement. In this system, "one question that is not determined by the legislation is whether the agreement to arbitrate must be made in writing (and, if so, precisely what is necessary to constitute writing) or may be made orally. It seems clear that the agreement may be made orally, although it is unlikely that such agreements will occur frequently". ${ }^{128}$ Here, the freedom of the form on arbitration agreement is deduced and is not clearly affirmed by the text as the French case. In terms of comparison, we prefer clarity as in France than the controversial deduction and it is also the rich experience for the countries which will consider the abandonment of the written form in matters of an arbitration agreement.

3. Abandoning writing requirement by adding another form

(a) Case of New Zealand: Concerning the way of abolishing the writing requirement of an arbitration agreement, we are also interested in knowing the solution of New Zealand.

Prior to the coming into force of the New Zealand Arbitration Act 1996, no distinction is drawn between a submission (an agreement to submit an already existing dispute to arbitration) and an arbitral clause. Both forms of agreement are "submissions" within the definition of the word "submission" in the 1908 Act (section 2) 129 . During this time in New Zealand, "to be a submission within the provisions of the 1908 Act, the agreement must be in writing". ${ }^{130}$

New Zealand adopted the new Arbitration Act in 1996 and this Act is substantially based on the Model Law. In fact, the 1996 Act includes the Model Law in its First Schedule (Model Law, as adopted, reproduced in Schedule 1 to the Act1996) and "the principal modifications of the Model Law in Sch 1 to the principal Act are as follows: form of arbitration agreement (art 7) — the agreement may be oral". ${ }^{131}$ Here, "this is a departure from the Model Law"132 because Art. 7 of the First Schedule "significantly, provides for the Act to apply

\footnotetext{
128 Malone B (2019)., 'National Report for Scotland (2019)', in Paulsson J. (ed), supra note 10, p.8.

129 Kennedy-Grant T. (1983), 'National Report for New Zealand (1983-1986)', in Berg A. J. V. D. (ed), Yearbook Commercial Arbitration, ICCA \& Kluwer Law International, p.36.

$130 \quad$ Ibidem., p.36.

131 Kennedy-Grant T. (2008), 'The New Zealand Experience of the UNCITRAL Model Law: A Review of the Position as at 31 December 2007', Asian International Arbitration Journal, p.5.

132 Williams D. A. R. (2019), 'National Report for New Zealand (2016 through 2018)', in Paulsson J. (ed), supra note 10, p.8.
} 
to oral arbitration agreements". ${ }^{133}$

(b) Comparison of solutions: In fact, according to Art. 7 of the First Schedule, "An arbitration agreement may be made orally or in writing". Here, beside the written form, the law adds another possible form for the arbitration agreement and this gives more freedom to the parties in the formation of an arbitration agreement. However, such a way of abandoning the writing requirement is undesirable because it does not make it possible to know whether other forms of the arbitration agreement are possible. We are not sure that forms other than written and oral are possible for the arbitration agreement as to the cases where the arbitration agreement is formed by tacit acceptance, conduct or performance. Therefore, if a country wishes to abandon the written form for the arbitration agreement, we do not advise to follow the way of New Zealand, the Belgian way is preferable and the French way is best.

\section{B. Scope of Abandonment of the Writing Requirement}

\section{Full abandonment}

(a) Norwegian law 2004: On arbitration, there are some theories of "monism" and "dualism" to describe the relationship between the sets of rules that deal with national and international legal issues. Dualism is the system where a country has two different sets of rules for national and international arbitration. The adoption of one single law for national as well as international arbitration corresponds to a monistic system.

We saw in Norway that "there is no requirement under the Arbitration Act that the agreement be in writing. This represents an important change from the earlier position under the Civil Procedure Act of 1915 and also compared to the Model Law at the time of the passing of the Arbitration Act in 2004. Whether the parties have validly agreed on arbitration will be established from an assessment of the factual and legal circumstances of the case". ${ }^{134}$ In reality, this "Act applies to international and domestic arbitration". ${ }^{135}$

Therefore, elimination of written form in Norway applies to domestic arbitration as to international arbitration and, in both cases, the parties are free to choose the form of their arbitration agreement under Norwegian law.

(b) Scottish law 2010: The same solution is found in Scotland where "there is no express provision in the 2010 Act stating that the

\footnotetext{
133 Kennedy-Grant T. (1997), 'New Zealand', in Berg A. J. V. D. (ed) (1997), Yearbook Commercial Arbitration, ICCA \& Kluwer Law International, p. 578.

Ryssdal A. and Myrbakk K. S., supra note 95, p.5.

Ibidem., p.1.
} 
arbitration agreement must be in writing". ${ }^{136}$ In this system, the 2010 Act established a single regime covering all arbitrations ${ }^{137}$ and does not impose any formal requirements. So, there is also no distinction between domestic or international arbitrations about the form of an arbitration agreement. It means that, for these two arbitrations, the parties are free to choose the form of their arbitration agreement.

(c) Belgian law 2013: We understand that Reform of 2013 in Belgium "does not require that the arbitration agreement consists of an instrument in writing signed by the parties, as was the case under the previous legislation where a written instrument was required". ${ }^{138}$ With this Reform, "an arbitration agreement does not need to be in writing"139 and "the parliamentary documents provide that the arbitration agreement can be verbal as long as it can be proved. For example, if the existence of the arbitration agreement can be proved by witnesses. The performance of the arbitration agreement may also, of course, prove its existence. This is the case when parties present themselves voluntarily, without objection, in front of the arbitrators and take part in the arbitral procedure". ${ }^{140}$

In reality, Belgium opted for a monistic system of arbitration law and "provided for these rules to apply equally to both national and international arbitration. This choice is in accordance with the former arbitration law, which, in principle, did not make a distinction between national and international arbitration either". ${ }^{141}$ With the adoption of one single law for domestic as well as international arbitration, B.J.C. applies to domestic and international arbitration.

In other words, there is no distinction between domestic or international arbitrations about the form of an arbitration agreement and, in both cases, the parties are free to choose the form of their arbitration agreement under Belgian law.

\section{Partial abandonment}

(a) French law 2011: We also understand that the Model Law offers Option II to eliminate the formal requirement. However, the Model Law was constructed to regulate international arbitration without the intent of interfering with rules on national arbitration ${ }^{142}$ and French law adopt this view in the formal requirement.

Wilson D., supra note 88, p.685.

Dundas H. R., supra note 107, p.90.

Dal M., supra note 117, p.99.

Verbist H. (2013), 'New Belgian Arbitration Law of 24 June 2013 and New CEPANI

Arbitration Rules of 1 January 2013', Journal of International Arbitration, p.600.

Dal M, supra note 117, p.99.

Piers M. and Meulemeester D. D., supra note 114, p.151.

Ibidem., p.149. 
In France, the Legislation of 1981 distinguished between national and international arbitration. The French reforms of 2011 also make a distinction national with international arbitration in the context of formal requirement. In fact, Article 1507 of the French CCP provides that "The arbitration agreement is not subject to any formal requirement".

Today, "under French international arbitration law, an arbitration agreement does not need to be in writing and does not need to be signed by the parties to the arbitration. Rather, an agreement to arbitrate may exist whenever evidence is provided that there is a "common intent of the parties' to arbitrate their disputes". ${ }^{143}$

(b) Comparison between full and partial abandonment: So, with Article 1507 of the French CCP, the law gives the parties wide contractual freedom in this field. It is not required that the arbitration clause be made in writing. ${ }^{144}$ However, this article applies only to the international arbitration and French law requires domestic arbitration agreements to be in writing because Article 1443 of the French CCP for domestic arbitration provides that "on pain of nullity, the arbitration agreement is written".

We think that the solution in Belgium, Norway, Scotland and New Zealand $^{145}$ is better than the French solution and it is preferable to not require the writing for the arbitration agreement.

For the long term, it is desirable that the abandonment of formal requirement also applies to arbitration agreement for domestic arbitration because, according to a French doctrine, "this difference is not appropriate since nothing justifies such a difference in the solutions"146 and we are still awaiting a change regarding the written form of the arbitration agreement on domestic arbitration. ${ }^{147}$

3. Weak party protection

(a) Protection of consumers: The high costs (both of the arbitration procedure itself and of advice), the procedural difficulties (in particular the distance from the seat of the arbitration to the consumer's domicile) as well as the economic inequality between the consumer and the trade operator are generally criticized for arbitration. Arbitration, therefore,

$143 \quad$ Bensaude D., supra note 77, p.1136.

144 El-Ahdab A. H. and El-Ahdab J., supra note 55, p.60.

145 See infra.

146 Racine J.-B., Droit de l'arbitrage, supra note 39, p.195.

147 An French author notes that "the difference with the domestic arbitration regime is striking. Indeed, the rule in this area is diametrically opposed. One would have expected the decree of January 13, 2011 to liberalize the rules. It has not happened”' (Racine J.-B., 'Fasc. 750', supra note $\left.63, n^{\circ} 22\right)$. 
has disadvantages for the consumer and measures should be taken to protect him. ${ }^{148}$

We see that New Zealand very soon abandoned the requirement of the written form for the arbitration agreement and this abandonment is maintained to nowadays. In fact, one "of the Arbitration Act's objectives is consistency between the law applicable to international and domestic arbitrations"149 and "the 1996 Act includes the Model Law in its First Schedule, which applies equally to international and domestic arbitrations". ${ }^{150}$ Since 1996, New Zealand no longer requires the written form for the arbitration agreement and, as to the extent of abandonment, the absence of the written form applies then to all arbitrations.

However, "in October 2007, the principal Act was amended to give effect to the majority of the Law Commission's recommendations by further strengthening the protection given to consumers under s 11 of the Act". ${ }^{151}$

(b) Content of protection: With the Arbitration Amendment Act 2007 in New Zealand, "special formalities must be met where a person enters into an arbitration agreement as a consumer if that agreement is to be enforceable against that person". ${ }^{152}$

So, "the rule that an arbitration agreement may be made orally or in writing is subject to one exception. Under Sect. 11 of the 1996 Act, an arbitration agreement in a contract entered into between a consumer and a trader is only enforceable against the consumer if: (1) the consumer, by separate written agreement entered into by the consumer and the trader after a dispute has arisen out of, or in relation to, the contract, certifies that, having read and understood the arbitration agreement, the consumer agrees to be bound by it; (2) the separate written agreement discloses, if it is the case, the fact that all or any of the provisions of Schedule 2 to the Act do not apply to the arbitration agreement in question". ${ }^{153}$

$\overline{148} \quad$ See our study: "Le règlement des litiges entre consommateur et professionnel par voie d'arbitrage: Regards croisés vietnamo-français", in Mélanges Jacques Mestre, Nxb. LGDJ 2019, pp.423-435; Fabbri M. P. (2018), 'Inapplicability of the arbitration agreement due to the impecuniosity of the party', Revista Brasileira de Arbitragem, pp. 67-96.

149 Kawharu A. (2007), 'The Public Policy Ground for Setting Aside and Refusing Enforcement of Arbitral Awards', Journal of International Arbitration, p.511.

$150 \quad$ Ibidem., p.493. This author (Ibidem.) notes that "In its 1991 Arbitration Report, the Commission recommended the adoption of the UNCITRAL Model Law for both international and domestic arbitrations, together with additional provisions to apply presumptively to domestic arbitrations. Its recommendations were largely accepted and the new legislation was finally passed in 1996".

151 Kennedy-Grant T., supra note 131, p.7.

152 Ibidem., p.5.

153 Williams D. A. R., supra note 132 , p.8. 
Contrary to the freedom of the parties, this solution of New Zealand is however still to be encouraged to protect the weak parties. It is also a rich experience for the countries that will consider the abandonment of the written form in matters of an arbitration agreement.

\section{CONCLUSIONS}

An arbitration agreement is the expression of the intent of the parties to withdraw their disputes from a national court system and to submit them to arbitration. Conventions on international arbitration statutes generally require a written agreement for the arbitration agreement. Influenced by these Conventions, notably by the New York Convention, a lot of national arbitration laws require arbitration agreements to be in writing.

A writing requirement reigned supreme for decades. However, there is a trend and some "pro-arbitration jurisdictions, like France, have abandoned the writing requirement". ${ }^{154}$ With this abandonment, we couldn't exclude cases involving acceptance by performance, conduct or tacit acceptance and we must also admit the purely oral agreements (as the oral offer which contains a reference to a text, orally accepted), the oral acceptance without any performance or conduct (for example, where a buyer agrees orally to purchase goods, but then fails to take delivery of them).

Some countries no longer require this written form for a long time and this does not pose a major practical problem like New Zealand, Sweden, France ${ }^{155}$ which is still a big hit for international arbitration. ${ }^{156}$ We can say that a number of countries had no requirement for arbitration agreements to be concluded in writing, a situation which did not create problems with respect to proving an arbitration agreement since evidence of the existence of an agreement could be produced in any way that would suffice to prove the existence of a contract under general law. ${ }^{157}$

$154 \quad$ Villaggi F., supra note 38, 3.3 .

155 This abandonment in France is clearly stated in the text since 2011 but "leading commentators have confirmed that French law was no different prior to the reform of 2011" (Brekoulakis S., Lew J. D. M., and al. (eds) (2016), The Evolution and Future of International Arbitration, International Arbitration Law Library, p.211). In fact, the Paris Court of Appeal had stated in 2005 that "the international arbitration agreement does not obey any rule of form, but a principle of validity which is based solely on agreement of the parties" (CA Paris, 24 févr. 2005, Sidermetal).

156 According to the International Arbitration survey conducted in 2018 by the School of International Arbitration at Queen Mary University of London, Paris remains one of five most preferred seats of arbitration in the World.

157 Holtzmann H. M., Neuhaus J. and al., supra note 2, p.67. 
This study shows that these are further reasons to abandon the written form requirement ${ }^{158}$ and, in accordance with the needs and practice of the modern business life, it strongly supports the progressive abolition of the writing requirement of the arbitration agreement for the future in national arbitration laws.

\section{Reference \\ Books}

[1] Ancel M.-E., Deumier P. and Laazouzi M. (2017), Droit des contrats internationaux, Sirey

[2] Bassiri N. and Draye M. (eds) (2016), Arbitration in Belgium, Kluwer Law International

[3] Bosman L., (ed) (2019), ICCA International Handbook on Commercial Arbitration, ICCA \& Kluwer Law International

[4] Born G. B. (2014), International Commercial Arbitration, Kluwer Law International

[5] Brekoulakis S., Lew J. D. M., and al. (eds) (2016), The Evolution and Future of International Arbitration, International Arbitration Law Library

[6] Gaillard E. and Savage J. (eds) (1999), Fouchard Gaillard Goldman on International Commercial Arbitration, Kluwer Law International

[7] Gomez K. F. and Lopez-Rodriguez A. M., (eds) (2019), 60 Years of the New York Convention: Key Issues and Future Challenges, Kluwer Law International

[8] Holtzmann H. M., Neuhaus J. and al. (2015), A Guide to the 2006 Amendments to the UNCITRAL Model Law on International Commercial Arbitration: Legislative History and Commentary, Kluwer Law International

[9] Leaua C. and Baias F.-A. (eds) (2016), Arbitration in Romania: A Practitioner's Guide, Kluwer Law International

[10] Lew J. D. M., Mistellis L. A. and Kroll S. (2003), Comparative International Commercial Arbitration, Kluwer Law International

[11] Mistelis L. A. (2015), Concise International Arbitration, Kluwer Law International

[12] Racine J.-B. (2016), Droit de l'arbitrage, Puf

[13] Paulsson J. (ed) (2019), ICCA International Handbook on Commercial Arbitration, ICCA \& Kluwer Law International

[14] Sanders P. (ed) (1989), Arbitration in Settlement of International Commercial Disputes Involving the Far East and Arbitration in Combined Transportation, ICCA Congress Series, ICCA \& Kluwer Law International

[15] Berg A. J. V. D. (ed) (1978), Yearbook Commercial Arbitration, ICCA \& Kluwer Law International

[16] Berg A. J. V. D. (ed) (1982), Yearbook Commercial Arbitration, ICCA \& Kluwer Law International

[17] Berg A. J. V. D. (ed) (1987), Yearbook Commercial Arbitration, ICCA \& Kluwer Law International

[18] Berg A. J. V. D. (ed) (1999), Improving the Efficiency of Arbitration Agreements and Awards: 40 Years of Application of the New York Convention, ICCA Congress Series, ICCA \& Kluwer Law International

[19] Berg A. J. V. D. (ed) (2003), International Commercial Arbitration: Important Contemporary Questions, ICCA Congress Series, ICCA \& Kluwer Law International

[20] Berg A. J. V. D. (ed) (2013), International Arbitration: The Coming of a New Age?, ICCA \& Kluwer Law International

158 Landau T. T., supra note 25, p.62: still says that "there are compelling reasons to change or clarify the current form requirement. As a matter of logic, policy and practice, there is every reason to abandon the written form altogether. There is then the problem of what, in practice, should be done". 


\section{Journal articles}

[21] Hẹainlan S. A. (2012), 'The New Saudi Arbitration Act: A Comprehensive and Article-byArticle Review', International Journal of Arab Arbitration, p.24

[22] Caprasse O. (2013), 'Le nouveau droit belge de l'arbitrage', Revue de l'Arbitrage, p.959

[23] Castellane B. (2011), 'The New French Law on International Arbitration', Journal of International Arbitration, p.373

[24] Clay T. (2012), 'Liberté, Égalité, Efficacité: La devise du nouveau droit français de l'arbitrage Commentaire article par article (Deuxième partie)', Clunet n ${ }^{\circ}$ 3, doctr. 8, Article 1507

[25] Dundas H. R. (2010), 'The Arbitration (Scotland) Act 2010-A New Era Begins', Asian Dispute Review, p.108

[26] Dundas H. R. (2016), 'The Arbitration (Scotland) Act 2010: A Great Collaborative Success and an Innovative Model for Other Jurisdictions to Follow', Indian Journal of Arbitration Law, p. 89

[27] El-Ahdab A. H. (2009), 'The new Algerian arbitration law', International Journal of Arab Arbitration, pp. $9-87$

[28] Jarrosson C. and Pellerin J. (2011), 'Le droit français de l'arbitrage après le décret du 13 janvier 2011', Revue de l'Arbitrage, p.64

[29] Jarvin S. H. L. and Young B. (1999), 'A New Arbitration Regime in Sweden - The Swedish Arbitration Act 1999 and the Rules of the Stockholm Chamber of Commerce', Journal of International Arbitration, p.91

[30] Fan K., Stackpool-Moore R. and El-Ahdab J. (2014), 'Un point (de vue) actuel sur l'arbitrage en Chine et à Hong Kong: Toujours un pays, deux systèmes?', Revue de l'Arbitrage, p.838

[31] Finch J. and Aye T. (2016), 'International Arbitration Under Myanmar's Arbitration Law', Asian International Arbitration Journal, p.238

[32] Kawharu A. (2007), 'The Public Policy Ground for Setting Aside and Refusing Enforcement of Arbitral Awards', Journal of International Arbitration, p.511

[33] Kennedy-Grant T. (2008), 'The New Zealand Experience of the UNCITRAL Model Law: A Review of the Position as at 31 December 2007', Asian International Arbitration Journal, p.5

[34] Manitlla-Serrano F. (2004), 'La nouvelle loi espagnole du 23 décembre 2003 sur l'arbitrage', Revue de l'Arbitrage, p.241

[35] Mayer P. (1994), 'De l'autonomie de la clause compromissoire', Revue critique du droit international privé, p. 663

[36] Nourissat C. (2011), 'Le nouveau droit français de l'arbitrage (décret n 2011-48 du 13 janvier 2011 portant réforme de l'arbitrage)', $\mathrm{n}^{\circ} 3$ Procédures, étude 3 ( $\left.{ }^{\circ} 12\right)$

[37] Sippel H. (2017), 'An Overview of the Revisions to the New Korean Arbitration Act: Will Korea Now Become an East Asian Arbitration Hub?', German Arbitration Journal, pp. 90 - 95

[38] Piers M. and Meulemeester D. D. (2013), 'The New Arbitration Law - Belgium Adopted the UNCITRAL Model Law', Asian International Arbitration Journal, p.153

[39] Reetz C. R. (2009), 'Recent developments concerning the "writing" requirement in international commercial arbitration: a perspective from the United States', Spain Arbitration Review, p.30

[40] Sherer M. (1994), 'Some brief comments on the Draft of the new Swedish Arbitration Act', ASA Bulletin, p.282

[41] Sorieul R. (2005), 'UNCITRAL's Current Work in the Field of International Commercial Arbitration', Journal of International Arbitration, p.544

[42] Velissaropoulos-Karakostas J. (2000), 'L'arbitrage dans la Grèce antique-Epoques archaïque et classique', Revue de l'Arbitrage, p.18

[43] Villaggi F. (2018), 'Recent Developments in the Arbitration Legislation in Argentina', Journal of International Arbitration, pp. $225-252$

[44] Verbist H. (2013), 'New Belgian Arbitration Law of 24 June 2013 and New CEPANI Arbitration Rules of 1 January 2013', Journal of International Arbitration, p.600

[45] Weir M. E. L. (1987), 'Arbitration in Scotland', Journal of International Arbitration, p.36

[46] Wilson D. (2010), 'The Resurgence of Scotland as a Force in International Arbitration: The Arbitration (Scotland) Act 2010', Journal of International Arbitration, p.687 